\title{
Investigation of serum nitric oxide and malondialdehyde levels in cattle infected with Brucella abortus
}

\author{
Cevat NISBET ${ }^{1}$, Gül Fatma YARIM ${ }^{1}$, Alper ÇIFTCí $^{2}$, Sena ÇENESiZ ${ }^{1}$, Gülay ÇIFTCI $^{1}$ \\ ${ }^{1}$ Department of Biochemistry, Faculty of Veterinary Medicine, University of Ondokuz Mayis, Samsun; ${ }^{2}$ Department of \\ Microbiology, Faculty of Veterinary Medicine, University of Ondokuz Mayis, Samsun.
}

\begin{abstract}
Summary: The objective of this study was to determine serum nitric oxide (NO) and malondialdehyde (MDA) levels in cattle infected with Brucella abortus (B. abortus). Study cohort was comprised of 30 cattle aged between 2-3 years; 20 infected with $B$. abortus and 10 healthy cattle. B. abortus infection was determined in the animals by Serum Agglutination Test and Multiplex PCR assay. Serum NO level was determined by enzymatic Greiss reaction and MDA level by Yoshioka method. Mean serum NO and MDA levels of cases with confirmed B. abortus were $58.20 \pm 6.50 \mu \mathrm{mol} / \mathrm{L}$ and $2.25 \pm 0.10 \mathrm{nmol} / \mathrm{ml}$, respectively whereas those of the controls were $38.07 \pm 2.40 \mu \mathrm{mol} / \mathrm{L}$ and $1.74 \pm 0.25 \mathrm{nmol} / \mathrm{ml}$, respectively. We found that serum NO and MDA levels in infected cattle were significantly higher than healthy control cattle $(\mathrm{p}<0.05$ and $\mathrm{p}<0.01$, respectively). In conclusion, the increase in NO level in cattle infected with B. abortus is a result of stimulation of NO synthesis in macrophages by bacterial lipopolysaccharides, and the increase in MDA level is a result of excessive radical production due to brucellosis acting upon membrane lipids and can be used as an indicator of tissue damage.
\end{abstract}

Key words: Brucella abortus, cattle, malondialdehyde, nitric oxide.

\section{Brucella abortus ile enfekte sığırlarda serum nitrik oksit ve malondialdehit düzeylerinin araştırılması}

Özet: Bu çalışmanın amacı Brucella abortus (B. abortus) ile enfekte sığırlarda serum nitrik oksit (NO) ve malondialdehit (MDA) düzeylerini belirlemektir. Çalışmanın materyalini 20 adet B. abortus ile enfekte ve 10 adet sağliklı olmak üzere 2-3 yaşlarında 30 adet sığır oluşturdu. B. abortus infeksiyonunun tespiti Serum Aglutinasyon Testi ve Multipleks PCR ile gerçekleştirildi. Serum NO düzeyi enzimatik Greiss reaksiyonu ile MDA düzeyi Yoshioka metodu ile belirlendi. B. abortus ile enfekte sı̆̆ırlarda serum NO ve MDA düzeyleri sırası ile $58.20 \pm 6.50 \mu \mathrm{mol} / \mathrm{L}$ ve $2.25 \pm 0.10 \mathrm{nmol} / \mathrm{ml}$, kontrol sı̆̆ırlarda ise $38.07 \pm 2.40 \mu \mathrm{mol} / \mathrm{L}$ ve $1.74 \pm 0.25 \mathrm{nmol} / \mathrm{ml}$ bulundu. Enfekte sığırlarda serum NO ve MDA düzeylerinin sağlıklı kontrollerden istatistik olarak önemli oranda yüksek olduğu belirlendi (sırası ile, $\mathrm{p}<0.05$ ve $\mathrm{p}<0.01$ ). Sonuç olarak, NO düzeyindeki artışın bakteriyel lipopolisakkaridler ile makrofajlardan NO sentezinin uyarılmasının ve MDA düzeyindeki artışın da brusellozis enfeksiyonunun membran lipidlerini etkileyerek aşırı radikal üretimine neden olmasının sonucu olabileceği ve doku hasarının bir göstergesi olarak kullanılabileceği kanaatine varıld1.

Anahtar sözcükler: Brucella abortus, malondialdehit, nitrik oksit, sığır.

\section{Introduction}

Brucellosis, caused by bacteria of the genus Brucella, is a zoonotic infection with acute or chronic course and characterized by late-term abortions infertility, mastitis, orchitis and arthritis $(16,18)$. Among Brucella (B.) species the ones important for humans and animals are B. abortus, B. melitensis and B. suis $(4,33)$. The disease has considerable economic consequences for every country where stockbreeding is a significant means of subsistence secondary to abortions due to B. abortus, and reduced milk production. When the effects of the disease on public health are considered, the importance of the disease becomes more pronounced $(3,11)$. Free radicals, produced continuously as by-products during many normal cellular reactions can cause various damages in the organisms (27). Nitric oxide (NO) is a free radical molecule generated in biological systems by nitric oxide synthases (NOS). Because of its effect on neurotransmission, vasodilatation and immune response $(7,28)$. NO plays an important role in physiology, pathology, and pharmacology, which has stimulated extensive research interest $(22,35)$. In macrophages, NO production resulting from inducible NO synthase (iNOS) expression has been proposed as a host anti-microbial effector system, displaying activity against fungi, bacteria and parasites (12). NO is a cytotoxic effector molecule, a regulator of apoptosis and lymphocyte migration, it modulates the $\mathrm{Th} 1 / \mathrm{Th} 2$ balance and is involved in the regulation of vascular tone, wound repair and other processes (26). Nitric oxide is produced by 
constitutive endothelial or neural NO synthesis, or in higher concentrations, by inducible $\mathrm{NO}$ synthase $\left(\mathrm{NOS}_{2}\right)$, through the 5-electron oxidation of the terminal guanidine- $\mathrm{N}_{2}$ of the amino acid L-arginine $(20,26)$. NO is an innate immune component with anti-Brucella activity (32).

Lipid peroxidation is known to have a role in aging, cancer and many infectious diseases. The mechanism of damage involves lipid peroxidation, which destroys cell memberanes with the release of intracellular components, such as lysosomal enzymes, leading to further tissue damage (10). Malondialdehyde (MDA) is a by-product of lipid peroxidation and used as an index of the rate of tissue reaction chain. In addition, MDA used as an indicator of oxidative stress in cells and tissues (5, 17, 23). In this study we aimed to investigate the changes in NO and MDA levels in cattle infected with B. abortus.

\section{Materials and Methods}

\section{Animals}

The study is carried out on a total of 30 cattle. Infected and control groups were comparable with respect to age and sex. Twenty cattle that showed clinical signs of Brucellosis comprised the experiment group while 10 clinically healthy cattle comprised the control group. None of the members of the control group had a history of fever, loss of appetite, fatigue, abortus and physical examination was normal. None of the animals were immunized. Venous blood samples were taken from patients and healthy bovines. Blood samples were centrifuged at $3000 \mathrm{rpm}$ for 10 minutes. Serum samples were stored at $-20{ }^{\circ} \mathrm{C}$ until analysis.

\section{Serological diagnosis of brucellosis}

Serologic diagnosis of brucellosis in blood was made by Serum Agglutination Test (SAT) (16). Sera samples were double diluted with saline ( $\mathrm{pH} 7.2)$ to give a range from $1 / 10$ to $1 / 640 ; 0.5 \mathrm{ml}$ of brucellosis antigen (Pendik Research and Control Institute, Istanbul) was added onto them and incubated at $37{ }^{\circ} \mathrm{C}$ for 20 hours. Results were compared to positive and negative control sera and a serum titer of $(++)$ reaction at $\geq 1 / 40$ dilution was evaluated as positive for brucellosis.

\section{Multiplex PCR assay}

DNeasy Tissue Kit (Qiagen) was used for preperation of genomic DNA from sera. DNA extraction was made according to the manufacturer's instructions. PCR assay conditions were determined according to Bricker and Halling (6). The reaction mixture consisted of $60 \mathrm{mM}$ Tris- $\mathrm{HCl}(\mathrm{pH} 9.0), 15 \mathrm{mM}\left(\mathrm{NH}_{4}\right)_{2} \mathrm{SO}_{4}, 1.5$ $\mathrm{mM} \mathrm{MgCl} 2,250 \mu \mathrm{M}$ each of the for deoxynucleoside triphosphates (dNTPs), and the five primer coctail (0.2 $\mu \mathrm{M}$ each B. abortus-, B. melitensis-, B.ovis-, and B. suis- specific primers and $1 \mu \mathrm{M}$ IS711-specific primer). One unit of Taq polymerase per $45-\mathrm{ml}$ reaction mixture was added before the reaction mixture was dispensed on the microeppendorf tubes. For assays involving extracted DNAs, $5 \mu \mathrm{l}$ per $50 \mu \mathrm{l}$ reaction mixture of target DNA was added. The samples were cycled $\left(1.15 \mathrm{~min}\right.$ at $95^{\circ} \mathrm{C}$, $2.0 \mathrm{~min}$ at $55.5{ }^{\circ} \mathrm{C}, 2.0 \mathrm{~min}$ at $\left.72^{\circ} \mathrm{C}\right) 35$ times in a thermalcycler. After the last cycle, the reaction mixtures were incubated for an additional $5 \mathrm{~min}$ at $72{ }^{\circ} \mathrm{C}$ before they were stored at $4{ }^{\circ} \mathrm{C}$. the products ere analyzed by electrophoresis through a $1.5 \%$ agarose gel, after which the gel was stained with ethidium bromide and photographed.

\section{Serum MDA and NO measurements}

Serum NO levels of the cattle were measured by enzymatic Greiss reaction (7). Serum lipid peroxide levels (MDA) were determined according to the method described by Yoshioka et al. (36).

\section{Statistical evaluation of the data}

One- way ANOVA test was used to assess statistical differences between infected and control group (29). Data are expressed as $\bar{X} \pm S_{\bar{X}}$. $P$ values $<.05$ were considered to be significant.

Table 1. Serum MDA (A) and NO (B) levels in infected with Brucella abortus and healthy cattle.

Tablo 1. Brucella abortus ile enfekte ve sağlıklı sığırlarda serum MDA ve NO düzeyleri.

\begin{tabular}{lccc}
\hline & $\begin{array}{c}\text { Infected } \\
(\mathrm{n}=20)\end{array}$ & $\begin{array}{c}\text { Control } \\
(\mathrm{n}=10)\end{array}$ & $\begin{array}{c}\mathrm{P} \\
\text { Value }\end{array}$ \\
\hline $\mathrm{NO}(\mu \mathrm{mol} / \mathrm{L})$ & $58.20 \pm 6.50$ & $38.07 \pm 2.40$ & $<0.05$ \\
$\mathrm{MDA}(\mathrm{nmol} / \mathrm{ml})$ & $2.25 \pm 0.10$ & $1.74 \pm 0.25$ & $<0.01$ \\
\hline
\end{tabular}

\section{Results}

\section{Serological findings}

Decision on whether or not cattle were infected based on antibody titers determined by SAT. SAT titers of $1 / 40(++)$ and over was taken as positive for the nonimmunized cattle.

\section{Multiplex PCR (M-PCR) findings}

A total of 30 serum samples were analyzed with Multiplex PCR assay. The samples of healthy cattle showed no band on M-PCR. The DNA's of the other 20 samples showed band on 498-bp and were identified as B. abortus.

\section{MDA and NO levels}

Figure 1 shows the data comparing the serum NO and MDA levels of patient and control groups. Mean serum NO and MDA levels of animals infected with $B$. abortus were $58.20 \pm 6.50 \mu \mathrm{mol} / 1$ and $2.25 \pm 0.10$ 
$\mathrm{nmol} / \mathrm{ml}$, respectively compared to $38.07 \pm 2.40 \mu \mathrm{mol} / \mathrm{l}$ and $1.74 \pm 0.25 \mathrm{nmol} / \mathrm{ml}$, respectively, of the control group. Mean NO and MDA levels of the patients were significantly higher than the control group $(\mathrm{p}<0.05$ and $\mathrm{p}<0.01$, respectively) (Figure 1).
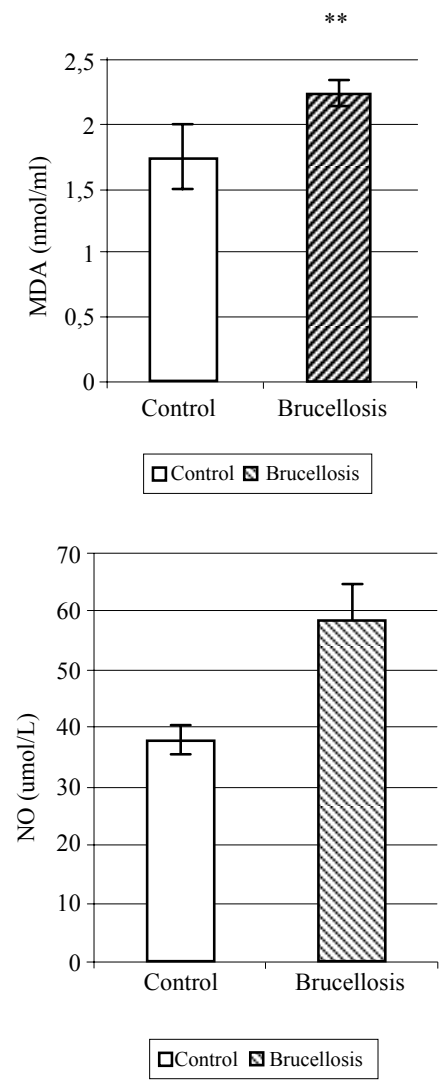

Figure 1. Serum MDA and NO levels in infected with Brucella abortus and healthy cattle.

Şekil 1. Brucella abortus ile enfekte ve sağlıklı sığırlarda serum MDA ve NO düzeyleri.

\section{Discussion and Conclusion}

The importance of this disease increases when the consequences on public health is considered in addition to the economic losses incurred by sending the infertile animals for breeding for slaughter and decrease in milk production (4, 11). These factors ascertain the importance of early diagnosis. Various clinical and experimental studies have tried to elucidate the role of oxidative stress in the pathogenesis of many diseases (10, 20). There is a balance between reactive oxygen species (ROS) produced in human and animal bodies and antioxidant defense (14). In case of an increase in ROS production in aging, cancer and various infections or decrease in antioxidant defense, free oxygen radicals react with macromolecules that contain protein, lipid and DNA and cause oxidative damage (32). ROS released from phagocytes alters the function of amino acids present in enzymes and kinases such as methionine, thyrosine and cysteine and causes tissue and cell damage $(14,27,37)$.
Nitric oxide plays an important role in macrophagemediated cytotoxic activity against a variety of pathogenes, including bacteria, viruses, fungi and protozoa $(12,17,32)$. Nitric oxide causes inhibition of certain enzymes responsible in oxidative phosphorylation through which ATP is synthesized; glycolysis and TCA cycle of the pathogens and tumor cells (31). On the other hand, by blocking the ribonucleotide reductase during DNA synthesis in these cells it exerts cytostatic effects on pathogen cells (21). In some research studies using NO inhibitors revealed functional impairment and damage in certain tissues whereas others found beneficial effects. Different results are due to the fact that NO is an antioxidant that inactivates superoxide and it produces radicals such as peroxynitrite (20). NO synthesis in macrophages is the first response to bacterial infections. In addition to its antibacterial efficacy, NO can exert effect by altering the immunity of the host depending on the concentration as well (1). Nitrite level is closely related to the endotoxin level and increased nitrite is a sign of poor prognosis $(7,20)$. In a study by Kubes and Mccafferty (19) have reported that when NO synthesis is inhibited in the first few hours after the endotoxin administration unfavorable effects have been observed on the small intestine and NOS inhibitors administered at $4^{\text {th }}$ hour had protective effects against endotoxin-induced damage.

Experimental and clinical studies carried out in recent years reported an increase in serum NO and MDA levels $(7,22)$. Serum NO levels of the infected cattle have been found significantly higher than the control group ( $\mathrm{p}<0.05$ ). This increase suggests that the increase may be a result of the response of phagocytic cells to infection. Urrutia et al. (32) carried out a study in which they induced experimental Brucella infections with B.abortus and B. melitensis and reported that NO levels were increased. Kandemir et al. (17) argued that nitrate was a sign of NO in some infections such as in gastroenteritis, septic shock and brucellosis. Same authors reported that nitrate levels in cases with Brucella infection were high and the level did not change after treatment (17). It has been sugested that high NO production would benefit the host by increasing Brucella killing during the early phase of infection. However, NO may not play a role in eliminating brucellosis during the late phase of infection and may favor bacterial growth (26). On the other hand, serum levels of nitrate and nitrite, NO products, in patients with cirrhosis were more increased compared to the control group and this increase showed parallelism with endotoxemia (13). In mice, NO production is a crucial component in the elimination of Brucella in vivo infections and the control of Brucella development by NO was confirmed in in vitro infections of mouse macrophages treated by IFN- $\gamma$ (11). Pfister et 
al. (28) investigated expression of iNOS and synthesis of NO was studied in listeric encephalitis of cattle, sheep, and goats. The level of iNOS expression and the density of cells per lesion expressing iNOS was highest in cattle, intermediate in sheep, and lowest in goats.

It has been reported that overproduction of free oxygen radicals that is related to antioxidant consumption causes oxidative stress (9). Increased free radical production and malondialdehyde (MDA) due to lipid peroxidation react with biological structures such as proteins, lipids, carbohydrates and DNA and cause damage $(2,25)$. One of the major products of lipid peroxidation, MDA has been reported to promote crosslinking bonds in the cell membrane and leads to unfavorable effects such as changes in ion permeability and enzyme activity (24). Lipid peroxidation is also responsible from tissue damage which causes ailments such as cancer, aging inflammatory diseases and atherosclerosis $(15,24)$. In the present study we looked into the MDA levels to evaluate lipid peroxidation induced by free radicals acting upon membrane lipids. MDA levels in cattles infected with brucellosis were significantly higher than the control group $(p<0.01)$. This shows that the balance of antioxidant enzymes is shifted in favor of free radicals and damage of the tissues may be induced in response to it. Many researchers $(1,7$, 28 ) have reported that numerous pathogens suppress the immune system by promoting free radical production and cause tissue damage. Madebo et al. (23) reported an increase in MDA levels in tuberculosis patients. In a similar study to ours, the authors reported that MDA levels were high in Brucellosis cases and that it dropped down to normal levels during recuperation after the treatment (17). Demir et al. (10) showed that MDA levels in patients with gastritis due to Helicobacter pylori was higher than the control group. It has been reported that in patients with pulmonary tuberculosis lipid peroxidation is increased and antioxidant enzymes are increased in response to it (30).

In conclusion, the increase in serum NO levels in cattle infected with $B$. abortus is due to the increased NO synthesis in the macrophages by bacterial lipopolysaccharides. On the other hand, increased MDA may be a result of excessive production of radical secondary to brucellosis itself acting upon membrane lipids. The results have lead to us believe that these can be used as indicators of tissue damage.

\section{References}

1. Akaike T, Maeda H (2000): Nitric oxide and virus infection. Immunology, 101, 300-308.

2. Atroshi F, Parantainen J, Sankari S, Jarvinen M, Lindberg LA, Saloniemi H (1996): Changes in inflammation-related blood constituents of mastitic cows. Vet Res, 27, 125-132.

3. Aydın N, Bisping $\mathbf{W}$, Akay $\mathbf{O}$, İzgür $\mathbf{M}$, Kirpal $\mathbf{G}$ (1988): Untersuchungen zum vorkommen boviner brucellose in derb Türkei bewertung der immunisierengen wirkung zweier vakzien. Berlin Münch Tieraerztliche Wschrft, 101,109-113.

4. Aydın N, Arda M, Akay Ö, İzgür M, Ayhan H, Esendal Ö, Aydın F (1990): Atık fetuslardan izole edilen brucella suşlarının ko-aglütinasyon testi ile identifikasyonları. Ankara Üniv Vet Fak Derg, 37, 348-358.

5. Bouchard L, Blais $\mathbf{S}$, Desrosiers $\mathbf{C}$, Zhao $\mathbf{X}$, Lacasse $\mathbf{P}$ (1999): Nitric oxide production during endotoxin-induced mastitis in the cow. J Dairy Sci, 82, 2574-2581.

6. Bricker BJ, Halling SM (1994): Differentiation of Brucella abortus bv. 1, 2 and 4, Brucell melitensis, Brucella ovis and Brucella suis bv. 1 by PCR. J Clin Microbiol, 32, 2660-2666.

7. Burgner D, Rockett K, Kwiatkowski D (1999): Nitric oxide and infectious diseases. Arch Dis Child, 81, 185188.

8. Cortas NK, Wakid NW (1990): Determination of inorganic nitrate in serum and urine by a kinetic cadmium reduction method. Clin Chem, 36, 1440-1443.

9. Czuczejko J, Zachara BA, Staubach-Topczewska E, Halota W, Kedziora J (2003): Selenium, glutathione and glutathione peroxidases in blood of patients with chronic liver diseases. Acta Biochim Pol, 50, 1147-1154.

10. Demir S, Yılmaz M, Köseoğlu M, Akalın N, Aslan D, Aydın A (2003): Role of free radicals in peptic ulcer and gastritis. Turk J Gastroenterol, 14, 39-43.

11. Fidancı HA, Akın S, Alabay M, Güvener N. (1995): Siğırlarda Brucella abortus'a karşı oluşan antikorları saptamada ELISA ve diğer serolojik tekniklerin karşıllaştırılması. Ankara Üniv Vet Fak Derg, 42, 553-557.

12. Gross A, Bertholet S, Mauel J, Dornand J (2004): Impairment of Brucella growth in human macrophagic cells that produce nitric oxide. Microb Pathog, 36, 75-82.

13. Guarner C, Soriano G, Tomas A, Bulbena O, Novella MT, Balanzo J, Vilardell F, Mourelle M, Moncada S (1993): Increased serum nitrite and nitrate levels in patients with cirrhosis: relationship to endotoxemia. Hepatology, 18, 1139-1143.

14. Halliwell B (1994): Free radicals and antioxidants:a personal view. Nutr Rev, 52, 253-265.

15. Inal ME, Kabak G, Sunal E (2001): Antioxidant enzyme activities and malondialdehyde levels related to aging. Clinica Chimica Acta, 305, 75-80.

16. Izgur M, Akay O, Arda M, Erdeger J (1992): Siğır brucellosisinin teşhisinde EDTA ve $56{ }^{\circ} \mathrm{C}$ 'de aglutinasyon testlerinin kullanılmast. Ankara Üniv Vet Fak Derg, 39, 191-200.

17. Kandemir O, Eskandari G, Camdeviren H, Sahin E, Kaya A, Atik U (2002): Plasma malondialdehyde and nitrate levels in patients with brucellosis. MEU Tip Fak Derg, 3, 405-409.

18. Kenar B (1990): Konya, Niğde, Nevşehir ve Kayseri illerinde koyun ve sı̆̆ır brusellozisinin sero-survey epidemiyolojik araştırması. Veterinarium, 1, 34-37. 
19. Kubes P, Mccafferty, DM (2000): Nitric oxide and intestinal inflammation. Am J Med, 109, 150-158.

20. Kuyumcu A, Düzgün AP, Özmen M, Besler T (2004): The role of nitric oxide in trauma and infection. Ulus Travma Derg, 10, 149-159.

21. Kwon NS, Stueh DJ, Nathan CF (1991): Inhibition of tumor cell ribonucleotide reductase by macrophagederived nitric oxide. J Exp Med, 174, 761-767.

22. Lowenstein CJ, Dinerman JL, Snyder SH (1994): Nitric oxide: a physiologic messenger. Ann Intern Med, 120, 227-237.

23. Madebo T, Lindtjorn B, Aukrust P, Berge RK (2003): Circulating antioxidants and lipid peroxidation products in untreated tuberculosis patients in Ethiopia. Am J Clin Nutr, 78, 117-122.

24. Marnett LJ (2002): Oxy radicals, lipid peroxidation and DNA damage. Toxicology, 27, 219-222.

25. McCord, JM (2000): The evolution of free radicals and oxidative stress. Am J Med, 108, 652-659.

26. Orozco G, Sánchez E, López-Nevot MA, Caballero A, Bravo MJ, Morata P, Colmenero JD, Alonso A, Martin J (2003): Inducible nitric oxide synthase promoter polymorphism in human brucellosis. Microbes Infect, 5, 1165-1169.

27. Pernet P, Coudray-Lucas C, Le Boucher J, Schlegel L, Giboudeau J, Cynober L, Aussel C (1999): Is the L-arginine-nitric oxide pathway involved in endotoxemiainduced muscular hypercatabolism in rats. Metabolism, 48, 190-193.

28. Pfister H, Remer KA, Brcic M, Fatzer R, Christen S, Leib S, Jungi TW (2002): Inducible nitric oxide synthase and nitrotyrosine in listeric encephalitis: a cross-species study in ruminants. Vet Pathol, 39, 190-199.

29. Rao CR (1973): Linear Statistical Inference and Its Applications. John\&Sons, New York.

30. Safarian MD, Karagezian KG, Karapetian ET, Avanesian NA (1990): The efficacy of antioxidant therapy in patients with tuberculosis of the lungs and the correction of lipid peroxidation processes. Probl Tuberk, 5, 40-44.
31. Taylor-Robinson, AW, Severn AW, Phillips RS (1996): Kinetics of nitric oxide production during infection and reinfection of mice with Plasmodium chabaudi. Parasite Immunol, 18, 425-430.

32. Urrutia LL, Alonso A, Nieto ML, Bayon Y, Orduna A, Crespo MS (2000): Lipopolysaccharides of Brucella abortus and Brucella melitensis induce nitric oxide synthesis in rat peritoneal macrophages. Infect Immun, 68 , 1740-1745.

33. Uysal Y (1998): Siğır ve koyun atıklarında brucellaların önemi. Ulusal Sığır ve Koyun Yavru Atma Sempozyumu 06-08 Ekim 1998. Pendik Hayvan Hastalıkları Araştırma Enstitüsü, İstanbul.

34. Wang M, Qureshi N, Soeurt N, Splitter G (2001): High levels of nitric oxide production decrease early but increase late survival of Brucella abortus in macrophages. Microb Pathog, 31, 221-230.

35. Wang Y, Li Q, Hu S (2005): A multiwall carbon nanotubes film-modified carbon fiber ultramicroelectrode for the determination of nitric oxide radical in liver mitochondria. Bioelectrochemistry, 65, 135-142.

36. Yoshioka T, Kawada K, Shimada T, Mori M (1979): Lipid peroxidation in maternal and cord blood and protective mechanism aganist actived oxygen toxicity in the blood. Am J Obstet Gynecol, 135, 372-376.

37. You D, Ren X, Xue Y, Luo G, Yang T, Shen J (2003): $A$ selenium-containing single-chain abzyme with potent antioxidant activity. Eur J Biochem, 270, 4326-4331.

Geliş tarihi: 13.09.2006 / Kabul tarihi: 15.02.2007

Address for correspondance
Yrd.Doç.Dr. Cevat Nisbet
Ondokuz Mayis University
Faculty of Veterinary Medicine
Department of Biochemistry - Kurupelit-Samsun
e-mail: cnisbet@omu.edu.tr

